\title{
Ventricular arrhythmias arising from valvular structures - a look at the valve disease through an ECG
}

\author{
(D)Matija Marković* \\ Divica Premužić \\ Meštrović, \\ (D)Tomislav Letilović
}

University Hospital "Merkur", Zagreb, Croatia

\author{
KEYWORDS: premature ventricular complexes, ventricular arrhythmias, outflow tract, catheter abla- \\ tion. \\ CITATION: Cardiol Croat. 2021;16(9-10):312. | https://doi.org/10.15836/ccar2021.312 \\ *ADDRESS FOR CORRESPONDENCE: Matija Marković, Klinička bolnica Merkur, Zajčeva 19, \\ HR-10000 Zagreb, Croatia./ Phone: +385-1-2253-205 / E-mail: matija.markovic@kb-merkur.hr \\ ORCID: Matija Marković, https://orcid.org/0000-0002-2852-3730 • Ivica Premužić Meštrović, https://orcid.org/0000-0002-2592-8302 \\ Tomislav Letilović, https://orcid.org/0000-0003-1229-7983
}

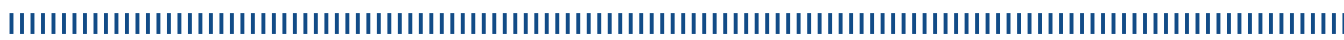

Cardiologists are familiar with valvular heart diseases but often they do not perceive heart valves as source of ventricular arrhythmias (VA). In patients with structural heart disease (SHD) VAs originate from a substrate in diseased myocardium, while in patients without SHD most common origins are outflow tracts (OT) ${ }^{1}$. Premature ventricular complexes (PVC) from OT are either from subvalvular, valvular or supravalvular myocardium as there are myocardial extensions above the semilunar valves, these VAs are created predominantly by mechanism of triggered activity or enhanced automaticity ${ }^{1,2}$ Papillary muscles, mitral and tricuspid anulus, aortomitral continuity and other sites in a structurally normal heart can also be the origin VAs. There are general and specific ECG characteristics that can localize the origin of VAs: bundle branch block type, axis, QRS polarity in lead V6, QRS duration, precordial transition, maximal deflection index, and so forth, therefore mapping of the PVC starts in the region that is presumed by ECG characteristic ${ }^{3}$. While different anti-arrhythmic drugs (AAD) aim at different mechanisms; calcium channel blocker can suppress triggered activity and beta-clocker can suppress automaticity, in general ablation is more effective in clinically meaningful reduction of PVCs compared to AAD (up to $95 \%$ vs. up to $25 \%)^{4}$. Ablations are generally safe but complication rates of catheter ablation in aortic root are not negligible and include myocardial rupture and tamponade, stroke, valvular damage, and coronary artery occlusion; these complications can be lowered by usage of intracardiac ultrasound (ICE) $)^{1,4}$. When mapping arrhythmias from the valves, we should stop perceiving the heart structures or valves as isolated parts and acknowledge that regional anatomy of these structures is among the most complex of those encountered by cardiac electrophysiologists, e.g., aortic valve is directly related with both atria, the interatrial septum, the right ventricular outflow tract and pulmonary valve, and the aortomitral continuity. Ablation is highly effective in suppression of PVCs, it has low numbers of complications, but ablation in aortic region brings serious complications to the table, therefore shared decision making with the patient and usage of ICE is of upmost importance.

LITERATURE IIIIIIIIIIIIIIIIIIIIIIIIIIIIIIIIIIIIIIIIIIIIIIIIIIIIIIIIIIIIIIIIIIIIIIIIIIIIIIIIIIIIIIIIIIIIIIIIIIIIII

1. Cronin EM, Bogun FM, Maury P, Peichl P, Chen M, Namboodiri N, et al; ESC Scientific Document Group. 2019 HRS/EHRA/APHRS/LAHRS expert consensus statement on catheter ablation of ventricular arrhythmias. Europace. 2019 Aug 1;21(8):1143-1144. https://doi.org/10.1093/europace/euz132

2. Gami AS, Noheria A, Lachman N, Edwards WD, Friedman PA, Talreja D, et al. Anatomical correlates relevant to ablation above the semilunar valves for the cardiac electrophysiologist: a study of 603 hearts. J Interv Card Electrophysiol. 2011 Jan;30(1):5-15. https://doi.org/10.1007/10840-010-9523-3

3. Yamada T. Twelve-lead electrocardiographic localization of idiopathic premature ventricular contraction origins. J Cardiovasc Electrophysiol. 2019 Nov;30(11):2603-2617. https://doi.org/10.1111/jce.14152

4. Marcus GM. Evaluation and Management of Premature Ventricular Complexes. Circulation. 2020 Apr 28;141(17):1404-1418. https://doi.org/10.1161/CIRCULATIONAHA.119.042434 $\square$ Cardiologia Croatica 2021;16(9-10):312.
5. kongres Radne skupine za bolesti srčanih zalistaka Hrvatskoga kardiološkog društva s međunarodnim sudjelovanjem $5^{\text {th }}$ Congress of the Working Group on Valvular Diseases of the Croatian Cardiac Society with international participation September 2-4, 2021, Zagreb, Croatia 